\title{
Memória e Esquecimento: uma relação indissociável nos relatos de mulheres que sobreviveram ao maior genocídio do século XX, o Holocausto
}

\author{
Memory and Forgetfulness: an inseparable relationship in the accounts of \\ women who survived the greatest genocide of the twentieth century, the \\ Holocaust
}

Sandra de Almada Mota Arantes

Centro Universitário de Formiga- UNIFOR/MG

\begin{abstract}
Resumo
Introdução: Esta investigação apresenta a temática do Holocausto com o enfoque em estudos relacionados à memória e ao esquecimento articulados a narrativas feitas por mulheres que sobreviveram a guetos e a campos de concentração na Segunda Guerra Mundial. Objetivo: Identificar por meio de revisão bibliográfica a manifestação da memória e do esquecimento em relatos de mulheres sobreviventes ao Holocausto para verificar a possibilidade de se reescrever uma história de reedificação da vida. Metodologia: utilizou-se a pesquisa bibliográfica, incluindo arquivos, teses, livros, revistas, relatos em sites especializados no tema, para verificar a relação entre memória e esquecimento. Resultados e discussão: As narrativas permitiram a elaboração da escrita feita pela volta ao passado, na intenção de se recuperar a memória do que ficou guardado e protegido por um esquecimento proposital para, depois, trazer a recordação de forma mais ou menos intacta para o presente. Há um exercício da memória em se esquecer de e se lembrar de. Pôde-se observar que os relatos mostraram o drama passado pelas mulheres, dentre eles trabalhos forçados, espancamentos, não raro, mortes enquanto tarefas eram executadas, casos de crueldade, crimes específicos de gênero, como abortos forçados, esterilização, prostituição forçada. Conclusão: Os estudos relacionados à memória e ao esquecimento articulados às narrativas feitas por mulheres sobreviventes ao Holocausto permitiram a confirmação de que há uma relação indissociável entre a memória e o esquecimento que leva à superação e à possibilidade de recomeçar a escrita de uma história.
\end{abstract}

Palavras-chave: Mulheres; História; Memória; Violência sexual feminina. 


\section{Abstract}

Introduction: This research presents the Holocaust theme with a focus on memory and forgetfulness studies articulated to narratives made by women who survived the ghettos and concentration camps in World War II. Objective: To identify, through bibliographic reviews, the manifestation of memory and forgetfulness in reports of women survivors of the Holocaust to verify the possibility of rewriting a history of rebuilding of life. Methodology: bibliographic research, including archives, theses, books, magazines, reports in virtual reality, was used to verify the relationship between memory and forgetfulness, and reports by women taken to concentration camps. Results and discussion: The narratives allow the elaboration of the writing of memory made by the return to the past, with the intention of recovering what was kept and protected by a purposeless forgetfulness and then bringing the memory more or less intact to the present. There is a memory exercise in forgetting and remembering. After the silence, women begin to report what they have lived through this inseparable relationship. The narratives for the reconstruction of history are accompanied by an alert, the intention to make known a history that should never be repeated. Conclusion: The studies related to memory and forgetfulness articulated to the narratives made by women who survived the Holocaust allowed the confirmation that there is an inseparable relationship between memory and forgetfulness that leads to overcoming and the possibility of resuming the writing of a story.

Keywords: Women; History; Memory; Female sexual violence.

\section{Introdução}

Memórias e histórias de mulheres é hoje um campo de pesquisa consolidado em universidades do mundo todo. Escrever sobre mulheres foi, por muito tempo, uma questão inconsistente ou ausente, e, ainda que tenha conquistado seu espaço nos mais diversos contextos, a escrita memorialística da história de mulheres revela, entretanto, que sua figura continua delimitada por conceitos conservadores que permanecem no seu imaginário e na sociedade.

Nos anos sessenta e setenta do século XX, época em que desenrolavam os movimentos feministas, surgiu o interesse em conhecer essa história escondida e silenciada. Para tanto, pesquisadores interessados no assunto voltaram seus olhares para arquivos particulares, autobiografias, diários íntimos e relatos com o objetivo de explorar e desvelar essa história.

Muitos dados ficaram no passado, junto às raízes de histórias vividas e, poucas vezes, contadas. Os fatos foram guardados na memória, esquecidos ali, com o objetivo de, depois, contar/escrever/documentar. E, ainda que em cacos de lembranças dos escombros, a memória garantiu a sobrevivência do passado.

$\mathrm{Na}$ busca de restaurar o que passou, agregou-se o vivido ao "sujeitando" da história presente. Despertouse, então, a vontade de lembrar e ser lembrado. As lembranças conservaram aquilo que se foi. E a memória tornou-se o penhor da própria identidade, o que se pode dizer do "eu" reunindo tudo o que se foi e fez a tudo que se é e se faz.

Santo Agostinho ${ }^{1}$ dizia chegar aos campos e aos vastos palácios da memória, lugar em que ficam os tesouros de inumeráveis imagens trazidas por percepções de toda espécie, onde repousa tudo o que a ela foi entregue. Ali encontrava a si mesmo e recordava suas ações em seu tempo, lugar, e os sentimentos que o dominavam ao praticá-las. Encontrava, ainda, todos os conhecimentos de que recordava, apreendidos pela experiência própria ou pela crença no testemunho de outrem.

É, é nessa perspectiva, fundamentada na relação memória e esquecimento, que se busca conhecer alguns capítulos sobre a história vivida por mulheres que sobreviveram ao Holocausto, período de uma história extremamente sombria e chocante.

Vale mencionar que a palavra Holocausto, termo grego - Holos "todo" e kaustos - que pode ser entendido como "queimado". Originalmente, referiase à oferta queimada, sacrifício em que animais eram totalmente queimados pelo fogo. No século XX, ganha o sentido de assassinato em massa (sentido usado neste artigo), referente ao genocídio de seis milhões de judeus, durante a Segunda Guerra Mundial, realizado pelo regime nazista na Alemanha.

A noção que se tem sobre essa época e o terror em que estava envolvida é bem vaga e, cresce, a cada dia, o número de pessoas jovens que não fazem ideia do que houve ou não a entendem plenamente. Verifica-se a possibilidade de, pela colheita de fragmentos e pela retomada de lembranças soterradas, elaborar o luto contido, para dar sentido e conhecer parte dessa história que ainda habita lugares os quais, um dia, foram palco da perda da identidade de um povo. Lugares marcados por cicatrizes e rastros que dão as pistas para a reconstrução de uma história que ficou aprisionada no âmago da alma, de modo latente, impedida de manifestar-se, emudecida pelo sofrimento. 
Para tratar de questões ligadas à memória e ao esquecimento, valeu-se aqui, dentre outros, de autores como Paolo Rossi, Paul Ricoeur, Henri Bergson e Arrigucci Júnior, e para os relatos de mulheres sobreviventes contou-se com entrevistas disponibilizadas no site Enciclopédia do Holocausto e Sarah Helm.

Com enfoque na importância de restaurar o que passou e não se deixar tudo para trás, correndo o risco de se enterrarem as lembranças para serem carcomidas junto à memória natural, pode-se deduzir que desvelar e reescrever um passado para documentá-lo é essencial à identidade de um povo. A partir desse pressuposto, $\mathrm{o}$ artigo teve como objetivo identificar por meio de revisão bibliográfica a manifestação da memória e do esquecimento em relatos de mulheres sobreviventes ao Holocausto para verificar a possibilidade de se reescrever uma história de reedificação da vida.

\section{Metodologia}

Delimitou-se a temática e o "recorte" teórico em estudos relacionados à memória e ao esquecimento articulados a narrativas sobre a história vivida por mulheres que sobreviveram ao Holocausto. Para tanto, utilizou-se a pesquisa bibliográfica, incluindo arquivos, teses, livros, revistas, relatos em realidade virtual; leitura e fichamento de textos a respeito do referido tema

\section{Resultados e discussão}

\section{A preparação para o extermínio}

Em 1933, na Alemanha, a ascensão de Adolf Hitler ao poder instaurou um governo totalitário o que desencadeou a Segunda Guerra Mundial. Em 1939, as tropas nazistas invadiram a Polônia e, desse ano até 1941, milhares de judeus tiveram a desapropriação de seus bens e foram deportados para um local chamado gueto, designação italiana para o bairro judaico de Veneza, criado para obrigar os judeus da cidade a ali viverem sob condições miseráveis, controlados e segregados. Para os alemães, essa era uma medida provisória, enquanto a liderança nazista, em Berlim, discutia as opções para concretizar a remoção daquela população.

Muitos foram deportados para campos de extermínio, a maioria para Auschwitz-Birkenau, onde eram obrigados a realizar trabalho escravo, até morrerem de exaustão, doenças ou fome. Muitos eram fuzilados e outros eram usados como cobaias em experimentos científicos. O extermínio era a morte em massa, nas câmaras de gás ou na "marcha da morte" termo criado pelos prisioneiros judeus para descrever a evacuação em massa dos campos de concentração.

Frases como "Me prometa que nunca vai deixar esquecer o que fizeram conosco", "Se sobreviver, não deixe de contar o que passamos" de Jacob Laks, mobilizam o dever de não se deixar tudo para trás, considera a possibilidade de descrever o passado, de documentar e firmar o compromisso de fazer conhecida tamanha atrocidade. ${ }^{2}$
Para tanto, usa-se a revivescência, força que arranca seu caráter transitório do que passou e entra como constitutivo no presente, aliada à escrita como garantia de que a memória sobreviverá um tempo maior, e não se correrá o risco de se enterrarem as lembranças para serem carcomidas junto à memória natural.

Em 1945, as barbáries praticadas pelos nazistas vieram à tona. Além dos números de mortos e das perdas materiais, ficaram marcas nas lembranças daquelas que sobreviveram à hostilidade. Dessas marcas e lembranças, muitas sobreviventes recolhem episódios e recontam para que as gerações vindouras conheçam suas histórias. Paradoxalmente, seus relatos evidenciam o desejo de silenciar para esquecer e o desejo de narrar para se libertar.

Nesse processo, entregam-se ao passado para recriá-lo no presente, e fazem o uso constante da memória, buscam o lugar onde viviam, que perderam, e que, para elas, já não existe mais.

Os fatos vividos outrora ficaram contidos e, elas, cientes de que não se poderia encerrá-los ou conserválos em um espaço estreito do cérebro, essa substância instável e perecível, conservaram-nos na alma, receptáculo amplo e estável, que por ser eterna, transcende o tempo.

Tamanha e tal capacidade para conter, para reter as coisas apreendidas não pode ser encerrada no espaço estreito do cérebro, nem pode ser conservada pela substância instável e perecível daquele, mas exige um receptáculo muito amplo e estável de uma alma divina (...). Certamente nunca vai definhar aquela substância cuja virtude profética antecipa, deste modo, todo o futuro, e cuja virtude potência mnemônica chama de volta todo o passado. Portanto, é uma substância eterna aquela que, num eterno momento, acolhe os intervalos caducos do tempo. ${ }^{3}$

Do ponto mais profundo da alma surgem as narrativas, compungidas lembranças as quais permitem a elaboração da escrita da memória feita pela volta ao passado, na intenção de recuperar o que ficou guardado, protegido por um esquecimento proposital para, depois, trazer a recordação de forma mais ou menos intacta para o presente.

Nesse exercício da memória se lembra de e se esquece de. Se lembra, é porque um dia esqueceu; se esqueceu, é para que um dia seja possível lembrar. Esquecer é uma arte, é preciso saber esquecer. $\mathrm{Na}$ verdade, o que se quer esquecer é aquilo de que melhor se lembra, pois, "a memória não só tem a incivilidade de não suprir a necessidade, mas também a impertinência de, frequentemente, aparecer a despropósito"3

É a memória que faz lembrar de se ter esquecido algo. Nela ficam a lembrança e o esquecimento, o que se vai lembrar e o que se vai esquecer. "O esquecimento suscita a memória e permite voltar-se para o esquecido"4 
Até os anos 80, não se discutia a experiência vivida pelas mulheres, no Holocausto. Talvez por medo ou vergonha, instaurou-se um silêncio a respeito do que aconteceu nos campos de concentração. Quando falavam, mencionavam o que alguma amiga ou irmã, havia passado. Hoje, o assunto começou a ser mais discutido e diante desse novo cenário, desembrulha-se a história de mulheres que sobreviveram e que, agora, tentam recontar/registrar para nunca deixar esquecer o que fizeram a elas e a suas famílias.

A maioria delas entende que, se sobreviveram, provavelmente, retêm o dever de contar. Deve-se cumprir hoje a missão de ouvir e escrever/reescrever, pois a escrita é arma para perpetuar a memória e para impedir que a história se perca na calada do esquecimento.

Os sofrimentos que enfrentaram eram, antes, evocados, apenas como rumores, fortes suspiros e olhares esquivos. Hoje, as sobreviventes acessam as essências perdidas no tempo, que poderão, via memória e lembranças, por meio de diferentes sensações, reviver o tempo passado ou o tempo em que os fatos se passaram. Na chamada do passado de volta ao presente, visualizam a época da destruição e escrevem suas histórias.

Hoje, talvez mais frágeis, porém mais vivazes, podem e conseguem lembrar, são capazes até de sentir o cheiro da morte que permanece e permanecerá, ainda, por muito tempo. Dentre as lembranças estão os números tatuados na pele, a fome, a nudez, a vergonha, os abusos, a perda do nome, o cheiro dos corpos queimados que exalava da fumaça que emergia das chaminés nas câmaras de gás.

As lembranças conduzem à recuperação do que aconteceu ao confirmar o que foi vivido, e a memória, por sua vez, cria um presente significativo. As sobreviventes desvelam as lembranças e percebem não querer, na verdade, apenas contar o capítulo de uma guerra, e das perseguições que sofreram, mas também sobrelevar que, na época, elas eram muito jovens, e essa fase foi arrancada de suas vidas.

Surge, então, uma escrita deprimente, pois os relatos de práticas e de crimes são para elas imperdoáveis. Não falam de feitos heroicos nem de façanhas admiráveis. Narram fatos de pessoas prontas a realizarem suas tarefas desapiedadamente humanas. E apesar de tanto sofrimento, depois de tantos anos, entendem que aquilo era a própria Vida, e foi essa a energia que as permitiu sobreviver para contar, ainda que contra a vontade, com a sanção de desaparecer assim, sem mais nem menos. Essa dor de se ter sobrevivido pode ser ouvida nas narrativas das angústias do que é irredutível, do resto, daquilo que sobrou depois de muito tempo, do remanescente.

Mas, convenientemente, narrar os segredos guardados por elas durante décadas torna-se catártico, pois reforça o conhecimento a respeito do Holocausto uma vez que o número de testemunhas vivas diminui a cada ano e vislumbra-se a possibilidade de vivenciar o luto a que tinham direito e do qual foram privadas.

Contar a história com suas próprias palavras, pode ajudar a enterrar os mortos do passado e ajudar a cavar um túmulo para aqueles de dele foram privados. É um trabalho de luto que ajuda os vivos a se lembrarem dos mortos para melhor viver o dia de hoje. $^{5}$

Diante dos relatos, as sobreviventes abrem-se, indefinidamente, contudo, na maioria das vezes elas se fecham, certamente ao (re)sentirem a dor, ao se perceberem diante das lacunas, dos mistérios. Todavia, a dor e o luto motivam a memória, e, ainda que descritos com cheiros de morte, os relatos revelam sabores de vida, desvelam o passado e ultrapassam o abismo que provocou um dos momentos limites da crueldade humana.

Ao vir à tona, o passado mistura-se às percepções imediatas do presente, o que aflora a consciência na forma de imagens-lembrança, as quais passadas para o papel, escapam da transitoriedade ${ }^{6}$.

Dá-se, então, a recriação do passado seja pela reconstrução documentada da memória voluntária, ou pela presentificação, recurso tão aleatório da memória involuntária. Lida-se sempre com o que falta na reconstituição irrealizável de um todo único e no fragmento imantado pelo conteúdo da experiência ${ }^{7}$.

Descrever o que aconteceu é um processo penoso demais, porém, ainda assim, deve-se falar, é preciso que elas sejam ouvidas para deixar escrito. As lembranças não se podem perder.

\section{A exumação do esquecimento}

A leitura das narrativas e relatos de mulheres alcança inumeráveis páginas o que torna cada vez mais clara a necessidade de conhecer com profundidade a história das lutas dessas mulheres. É impactante a força que tiveram, em situações nas quais é quase impossível encontrar resistência para aguentar tamanha violência. Recordar esses horrores é sempre pouco. É prudente que venha à tona como o ser humano é capaz de submeter o outro a brutais perseguições. Não se deve esquecer, o mal esquecido repete-se.

Elas trouxeram consigo, ao longo da vida, todas as experiências vividas durante aquele período, no entanto, não significa que encontraram facilidade em relatar suas histórias, transformando-as em matéria. Relatar para que outros as ouçam pode facilitar e incentivar a realização da dura tarefa que, ainda em elaboração, pode trazer a satisfação do dever cumprido. $^{8}$

A holandesa de origem judaica Nanette Konig não guarda segredo. Ficou em silêncio por muitos anos e, em 1990, começou a escrever, já era avó. Segundo a escritora, ela sobreviveu por acaso, por isso sente-se no dever de relatar o que aqueles, que sem voz, não o puderam fazer. Em seu livro "Eu sobrevivi ao holocausto", diz que gostaria de poder apagar o que viu e viveu, mas que de nada adiantaria esquecer, já 
que esquecer é perder de vez a sua família, seu povo. Diz ainda que o tempo escorre entre os dedos, portanto, é inadiável fazer do holocausto algo sempre presente, para que ninguém mais sofra nem perca a dignidade como aconteceu aos judeus, naquela época.

Eu me lembro de quando cheguei, mas não de quando saí. Quando você sofre uma subnutrição como nós sofremos, tem hora que falham as sinapses no cérebro, não tem memória"...(...)Minha mãe, em Bendorf, trabalhou 700 metros abaixo do solo em uma fábrica de partes de avião. Em abril de 1945, com 2000 mulheres ela foi colocada em um trem sem destino. Morreu cinco dias depois da partida... O campo onde eu estava era Bergen-Belsen, tinha pilhas $e$ mais pilhas de esqueletos, e o cheiro era insuportável, e obviamente eu, de vez em quando, pensava quando iria me juntar a eles, porque a situação era desesperadora. Era muito comum ouvirmos o som da morte enquanto estávamos dormindo: ouvíamos uma espécie de barulho assustador, como um ronco, e sabíamos que a pessoa estava morta - era o último suspiro antes de falecer. (...) ao contrário de Auschwitz, em Bergen-Belsen não ficou nada, queimaram o campo. Levaram-me de volta à Holanda, eu estava com 16 anos de idade... soube que eu era a única sobrevivente, quase enlouqueci. Depois eu me dei conta que... se eu queria viver, eu tinha que assumir o que restou. Quem sobrevive por acaso tem o dever de relatar porque, senão, aqueles que morreram, sem voz, ficam sem representação... ${ }^{9}$

No discurso de Konig, ${ }^{9}$ a memória manifesta-se carregada de sensações; as emoções exploram e reconstroem as imagens. Pelo mesmo fio-memória, evidencia-se a tensão existente entre a memória e o esquecimento. Recuperam lembranças de um passado torturado pelo vai e vem entre a memória e o esquecimento.

O mesmo sentimento manifesta-se no discurso de Ruth Webber, que aos quatro anos de idade viu os alemães invadirem a Polônia e ocuparem a cidade onde vivia, Ostrowiec. Seus pais foram enviados para um campo de trabalho escravo, e ela se escondia nas florestas próximas ao próprio campo. Aos seis anos, foi apanhada e enviada para diversos campos de concentração, até ser deportada para Auschwitz. Após a Guerra, enquanto não foi possível reencontrar sua mãe, Ruth viveu em um orfanato na Cracóvia. Em uma entrevista publicada online, na Enciclopédia do Holocausto, relata:

Eu vi muitas pessoas mortas bem de perto, em todos os lugares...uma vez, no campo em Ostrowiec Lager, eu estava no banheiro externo... de repente, houve uma comoção e todos os prisioneiros foram empurrados de volta para seus alojamentos, porque era para lá que eles tinham que ir, mas eu fiquei presa no banheiro...eu subi no vaso sanitário e olhei pela pequena janela que ficava em cima... algumas pessoas tinham tentado escapar, mas foram apanhadas...eu ouvia tiros... escolheram quatro prisioneiros para cavar covas do lado de fora da cerca de arame farpado... eles trouxeram aquelas pessoas que haviam tentado escapar, elas foram baleadas, mas não estavam mortas... fizeram os outros judeus enterrarem aquelas pessoas, ainda vivas... elas imploravam para não serem enterradas vivas, e pediam que as matassem antes de enterrá-las. Mas os alemães não tiveram pena, eles as enterraram vivas. E os judeus tinham que fazer aquilo, senão eles mesmos seriam mortos. Até hoje ainda posso ouvi-los gritando desesperados. ${ }^{10}$

Em alguns relatos, a memória traz os cheiros que reativam as lembranças, tornando-as quase palpáveis. Uma série delas veem à tona, e, então, inicia-se o vai e vem da memória, passado/presente; recordar/reviver. $\mathrm{O}$ cheiro torna-se uma ponte por onde se pode atravessar do presente para passado. Nesse movimento, o aroma das memórias invade a vida; Ruth Meyerowitz que morava em Frankfurt. Foi deportada para Auschwitz, em abril de 1943. Realizava trabalho escravo, tapando buracos nas estradas. Trabalhou na unidade "Kanada", separando os pertences originais das pessoas que haviam chegado aos campos e que eram roubados pelos alemães. Foi libertada em maio de 1945, durante uma marcha da morte que havia saído do campo de Malchow; em seu relato, ela dia sentir, ainda, o cheiro da carne humana queimada, como relata Ruth Meyerowitz:

O crematório ficava a apenas poucos minutos de distância. Podíamos ver as chaminés de onde quer que estivéssemos e nós éramos os primeiros a sentir o cheiro do gás quando ele era liberado das câmaras de gás. Em seguida, sentíamos o cheiro dos corpos queimando, da carne humana sendo queimada. Depois, ... eles limpavam os fornos e nós ouvíamos as trempes sendo limpas. $O$ barulho era parecido com o barulho que faz quando você puxa as trempes do seu próprio forno em casa, mas era muito, muito mais alto, e ouvíamos tudo de dentro das barracas. Até hoje, quando limpo meu próprio forno, eu me lembro daquele barulho da limpeza nas trempes no crematório. ${ }^{11}$

Essas mulheres armazenaram suas lembranças nos recônditos da memória as melhores, as piores, as mais tristes, as mais alegres, as mais incômodas, portanto, hoje, escolhem o que querem lembrar, substituem, algumas vezes, lembranças ruins por outras um pouco reconfortantes, e por meio de algumas até conseguem trazer paz à consciência. Em abril de 1944, Deutsch Madelina, nascida na Tchecoslováquia, e sua mãe foram enviadas para trabalhar como escravas em uma fábrica de munição, em Breslau. Ficaram um ano no subcampo de GrossRosen em Peterswaldau, até que em maio de 1945 as tropas soviéticas as libertaram. Chegaram a Nova York em março de 1949. Em seu relato lembra a imagem da mãe e o cuidado que tinha em alimentar, aquecer e garantir a sobrevivência da filha.

Minha mãe era uma mulher incrível. Ela estava com 43 anos. Agradeço a ela por ter sobrevivido, pois eu não sabia que quando ela tirou aquele pedaço de pão de mim para guardar para o resto dia, era para me dar um pedacinho a cada tantas horas para me 
ajudar a passar por tudo aquilo. Ela não só tinha me dado aquele pedaço de pão que era meu, ela tinha me dado o pedaço de pão dela, sem que eu soubesse, para que eu pudesse aguentar e sobreviver... Ela estava me dando um pedaço do pão dela, e eu só descobri o que ela fez depois que a Guerra acabou. Ela sempre me dava o até o último pedaço do que ela tivesse, ela me protegia, me cobria quando estávamos marchando, na chuva, na neve ou no frio. E tudo que tínhamos era um vestido cinza. ${ }^{12}$

As sobreviventes mostram a capacidade de sofrer e contar o que sofreu. E, agora, tornaram reconfortante o lembrar, o relatar e registrar suas duras histórias. Levam em conta a necessidade de escrever sem as censuras, sem os apagamentos, sem as ocultações, sem os sumiços, e sem as condenações.

Ao recontar, elas escutam a si mesmas, esquecem o "não quero me lembrar" e desenterram descrições humilhantes, esquecidas/reservadas, sobre as quais, hoje, já conseguem falar a respeito, como a chegada em um campo de concentração e as experiências ali vividas.

O campo de concentração Ravensbrück, localizado a 90 quilômetros ao norte de Berlim, foi construído exclusivamente para mulheres, mas abrigou também crianças, muitas delas nasceram ali, resultado dos abusos sexuais cometidos contra as prisioneiras.

Entre as prisioneiras de Lichtenburg transferidas para Ravensbrück estava Olga Benário Prestes, revolucionária e amante do maior nome do comunismo no Brasil, Luís Carlos Prestes. Viveu no período entre guerras e sofreu pela sua condição de judia e comunista. Morreu pelas mãos de Hitler e seu regime nazista, em uma câmara de gás, em Bernburg, no dia 23 de abril de 1942. Às vésperas de sua execução, escreveu uma carta de despedida a Carlos e Anita, sobre a qual seguem alguns trechos:

Amanhã vou precisar de toda a minha força e de toda a minha vontade...não posso pensar nas coisas que me torturam o coração, que são mais caras que a minha própria vida. ... despeço de vocês agora. $E$ impossível para mim, imaginar, filha querida, que não voltarei a ver-te,...poder pentear-te, fazer-te as tranças - ah, não, elas foram cortadas. Mas te fica melhor o cabelo solto, um pouco desalinhado... Carlos, querido, amado meu: terei que renunciar para sempre a tudo de bom que me destes? ...Quero-os a ambos, tanto, tanto. E estou tão agradecida à vida, por ela haver-me dado ambos...choro debaixo das mantas para que ninguém me ouça, pois parece que hoje as forças não conseguem alcançar-me para suportar algo tão terrível...esforço-me para despedir-me de vocês agora, para não ter que fazê-lo nas últimas $e$ difíceis horas...Lutei pelo justo, pelo bom e pelo melhor do mundo. Prometo agora, ao despedir-me, que até o último instante não terão por que se envergonhar de mim...preparar-me para a morte não significa que me renda, mas sim saber fazer-lhe frente quando ela chegue. Mas, no entanto, podem ainda acontecer tantas coisas... Até o último momento manter-me-ei firme e com vontade de viver. Olga Benário Prestes". 13

Os campos de concentração, inicialmente, ofereciam condições higiênicas e uniformes limpos, mas as punições e o trabalho escravo eram as normas. Com o avançar da guerra e com o número excessivo de prisioneiras as condições pioraram, havia fome, humilhações, morte, e uma maneira extremante cruel de execução. Ruth Borsos foi deportada para o campo de Westerbork em 1943 e para o campo de BergenBelsen, em 1944. Após a interrupção de um acordo de troca de prisioneiros entre nazistas e Aliados, Ruth ficou detida perto da fronteira suíça, até ser liberta pelas forças francesas, em 1945.comenta em seu relato sobre o trabalho escravo,:

No campo nós tínhamos que trabalhar estupidamente, sem sentido...ficar carregando areia de um lugar para o outro... tínhamos que obedecer. ...eles nos dividiam em diversas tarefas...eu fui designada para um lugar onde costurávamos roupas, não tenho certeza para quem. Era assim o dia inteiro. Às vezes, nós trabalhávamos na fazenda de um holandês, ele era nazista. ...mandava-nos limpar os chiqueiros, mandava-nos trabalhar em todas as áreas da fazenda, nos fazia trabalhar nas plantações de batata ou em qualquer outra coisa, para que ele não tivesse que trabalhar mais. Nós éramos escravas dele...lucrava pelo fato do campo ser tão perto e por ser nazista, por colaborar com os alemães. Como recompensa pelo nosso trabalho, ele nos sentava com as galinhas no quintal e nos dava uma sopa aguada para comer...era a única refeição do dia. ${ }^{14}$

No final da guerra, inúmeras mulheres haviam passado pelas portas de um campo de concentração. Sarah Helm publicou um livro sobre a capital do crime contra as mulheres, Ravensbrück: a história do campo de concentração nazista para mulheres, que traduz o maior campo construído especificamente para aprisionamento feminino. Um lugar onde eram totalmente violadas e desumanizadas; onde havia trabalhos forçados, espancamentos, não raro, mortes enquanto tarefas eram executadas, casos de crueldade, crimes específicos de gênero, como abortos forçados, esterilização, prostituição forçada. Depois de ter sido suspenso o uso de câmaras de gás nos campos mais ao leste da Europa, ainda foi construída uma câmara de gás em Ravensbrück. "Eles levaram partes das câmaras desmanteladas em Auschwitz, e, ali, exterminaram seis mil mulheres, este foi o último extermínio em massa da história do nazismo. ${ }^{15}$

Em Ravensbrück havia mulheres alemãs e austríacas. Várias internas eram judias, mas estas não eram a maioria. Havia prisioneiras políticas, ciganas, doentes mentais ou as chamadas "associais" prostitutas ou quaisquer mulheres consideradas inúteis pela doutrina nazista. As judias e as ciganas eram submetidas a experiências médicas que tinham como objetivo interromper o processo de reprodução desses grupos. Os procedimentos podiam ser fatais, irreversíveis, e ocasionavam traumas permanentes. A 
esterilização e os abortos sem consentimento eram práticas comuns ao plano de Estado nazista ligados ao controle populacional e à higiene racial. ${ }^{16}$

Hana Mueller Bruml foi confinada no gueto Theresienstadt, onde trabalhou como enfermeira. Em 1944, foi deportada para Auschwitz. Após um mês, foi emitida a Sackisch, onde fez a peça do avião no trabalho forçado. Ela foi libertada em maio de 1945. Seu relato, é sobre a marca deixada na chegada ao campo concentração

... tínhamos que nos despir, e depois passar por um corredor, todas nuas, exceto pelos sapatos. Veio um agente da SS e olhou para os nossos seios, para a nossa barriga, para ver se alguma de nós poderia estar grávida. Se eles vissem alguma mulher grávida, eles a mandavam para a morte... então, ficávamos paradas e nuas, e eles vinham e olhavam. (...)Depois raspavam o nosso cabelo. E me lembro de ver sentada, uma pessoa que eu conhecia com o cabelo comprido e, naquele momento, metade de sua cabeça estava raspada e a outra metade ainda tinha cabelos compridos. E eu olhei para ela, eu tinha alguns grampos de cabelo e os guardei. Eu pensei que quando o meu cabelo crescesse eu teria os grampos de cabelo...uma só lâmina era usada para centenas de pessoas. E depois, com a costumeira minúcia alemã, eles também rasparam nossos pelos pubianos. Cerca de 100 pessoas com uma lâmina apenas, sem higiene alguma. $^{17}$

$\mathrm{Na}$ primeira seleção, mulheres aptas ao trabalho eram levadas para uma sala onde ficavam nuas, tinham todos os pelos do corpo raspados para evitar as epidemias de tifo e passavam por um processo de desinfecção. A primeira água era extremamente quente. Depois do primeiro banho batiam nelas e as obrigavam voltar para debaixo do chuveiro, mas dessa vez com água bem gelada. Cecilie Klein-Pollack foi para o gueto em Huszt e, posteriormente, deportada para Auschwitz. Ela e sua irmã foram escolhidas para o trabalho forçado; o resto da sua família foi envenenada por gás na chegada. As forças Aliadas a libertaram em 1945. Ao narrar sua história no campo, menciona os chuveiros.

Eles nos fizeram marchar para um prédio enorme, havia toucas de banho, nos mandaram tirar as roupas. Eu era jovem ... vaidosa, estava vestida com as minhas melhores roupas, meu casaco bonito, meu melhor vestido...juntei as roupas com cuidado quando eu as tirei, veio uma Kapo e arremessou as roupas...disse que eu não precisaria mais delas... mandaram que todas ficassem de pé em um banco, e nos rasparam, rasparam nosso cabelo e nossas partes intimas...não podíamos nem mesmo reconhecer umas às outras, estávamos nuas, sem nossas roupas, sem nosso cabelo. Em seguida, nos empurraram para os chuveiros e abriram a água que nos queimava. Quando saíamos debaixo da água quente, ...nos bateram para que voltássemos para debaixo do chuveiro... abriram a água gelada, que teve o mesmo efeito. Deram um vestido para cada uma de nós alguns ficaram pequenos, muito pequenos, alguns ficaram muito grandes. Não nos deram, não recebemos nem roupa íntima, nem sutiã, nem calcinha, só aquele único vestido. ${ }^{18}$

As humilhações fizeram com que o "esquecer para lembrar" perdurasse por muito tempo. Entre o esquecer para lembrar, e o esquecer de lembrar, a memória refaz o tecido dessa história, sempre com os mesmos fios de um único e imutável trançado. O esquecimento, por sua vez, suscita questões como: as sobreviventes do Holocausto optaram pelo esquecimento involuntário ou firmaram um compromisso de esquecer por não querer contar o que ainda lembram? Pode o esquecimento ser desejável, manipulável, invasivo? Como acontece? Na mesma perspectiva da memória?

Nos estudos ricoeurianos, o esquecimento tem o mesmo nível de importância da memória e da história, e nele o passado se perde em sua dupla dimensão mnemônica e histórica. Na possibilidade da perda, ameaça se manifestar de forma inquieta nas tentativas de fenomenologia da memória e de epistemologia da história, tornando vulnerável a condição histórica. No âmbito da memória, a incidência do esquecimento sobre os processos mnemônicos de representação do passado se manifesta. Assim, o esquecimento revela seu caráter problemático, pretendendo ser fiel ao passado, propondo "eu posso fazer memória ..."19

Em muitos relatos, as histórias se "desembrulham" a partir de ações para lembrar e para esquecer, e pela memória, percebe-se o esquecimento manifesto no passado, nas coisas antigas que, vêm aos poucos surgindo no presente. Na tensão vivida, na vontade quase irrecuperável, o esquecimento revela-se com a possibilidade de refazer a memória. E é na angústia do conflito, que as sobreviventes acreditam na possibilidade de recuperar o passado e escrevê-lo, ainda que de forma difícil e árdua.

A historiadora Helenice Rodrigues comenta sobre esta dificuldade "Se, então, testemunhar é tentar preservar uma memória, para as testemunhas e/ou sobreviventes dos campos de concentração, narrar essa 'experiência limite' é atestar a impossibilidade de dizer e de traduzir o indizível". ${ }^{20}$

Em meio às dificuldades de se narrar, a memória e esquecimento desenvolvem um diálogo capaz de trazer uma inquietação constante e de construir a memória advinda da potencialidade do esquecimento. Esquecimento este denominado por Ricoeur ${ }^{19}$ de esquecimento de reserva, o qual possibilita que sejam formadas imagens de eventos passados e que sejam guardados eventos presentes para que se utilizem depois.

E no depois, muitas dessas lembranças surgem carregadas de humilhações e vulnerabilidades como aquelas que revisitam seus corpos. Gabriella Fischer, nasceu na Hungria, sobreviveu ao gueto de Busapeste, em uma entrevista concedida ao Núcleo de História Oral de São Paulo, revela parte dessas humilhações. Lembra de quando eram obrigadas a formar uma roda e entre cada mulher ficava uma fascista com um 
revólver. As prisioneiras deviam se abaixar com uma fascista às suas costas, e se aliviarem.

Eu morria de vontade urinar, mas não saía uma gota da minha bexiga. A humilhação... eu me sentia violentada, eu me cobri e voltamos com as outras pessoas e é claro que eu não aguentei. O corpo, o frio, aquele ar corrente gelado, a roupa fria no corpo. Eu não podia urinar nas calças... Eu fiz o que precisava fazer em frente deles. Essa foi outra coisa que...( silêncio)... tem tantas coisas que marcam. "21

Nos relatos, percebe-se desvelar o testemunho da dor de perder a identidade, como ressalta Lily Appelbaum Malnik, quando lembra de os alemães capturarem sua família. Lily escondeu sua identidade judaica por dois anos. Em 1944, foi denunciada por alguns belgas e deportada para Auschwitz-Birkenau. Após uma das marchas da morte de Auschwitz, foi liberta em Bergen-Belsen pelas forças britânicas uma das sobreviventes a qual também toca em pontos delicados, sobretudo sobre a vulnerabilidade de seus corpos diante da truculência.

Eles disseram: "De agora em diante, você não atende mais pelo seu nome. Seu nome é o seu número" [tatuado no braço]. Senti uma enorme tristeza, um desânimo, ... eu senti como se não fosse mais um ser humano. Eles tinham raspado nossas cabeças e eu me senti muito envergonhada. E, também, quando eles nos mandaram tirar a roupa e tomar banho, eles nos fizeram sentir como se nós fôssemos animais. Os homens [soldados nazistas] ficavam andando em volta da gente, rindo e olhando para nós. ${ }^{22}$

\section{A violência sexual no período do Holocausto}

As mulheres, além de humilhadas, de trabalhar sob condições que as levavam à morte, de serem usadas como cobaias em experimentos de esterilização, serem deixadas quase nuas na neve até morrerem, terem germes de sífilis injetados na medula espinhal, ter os músculos da pele cortados e inseridos neles vidro, madeira e terra, eram violentadas sexualmente. ${ }^{15}$

Irene Hizme tinha um irmão gêmeo, René. Em Auschwitz, foram separados e submetidos a cruéis "experiências médicas", ao mencioná-los, refere-se a coisas estranhas de se lembrar:

[...] tenho, infelizmente, muitas lembranças do hospital e do consultório médico. Parece-me que passei muito tempo lá, e... muito doente. Sei que uma vez, quando fui para o consultório médico, eles tiraram sangue de mim, e doeu muito porque foi do lado esquerdo do meu pescoço. Esta é uma coisa estranha de lembrar. Eu também me lembro de tirarem sangue do meu dedo, mas isso não era tão ruim. Lembro, também, de ter que ficar sentada, imóvel, por longos períodos para ser medida ou pesada, ou para radiografias. Eu me lembro de radiografias e mais radiografias, e injeções. Despois destas eu ficava doente e ficava naquele hospital. Lembro de ter tido febre alta, porque sei que eles estavam tomando minha temperatura. Eu realmente passei a odiar médicos. Passei a ter medo, eu costumava ter muito medo de médicos, eu ainda tenho. Eles são um pesadelo. ${ }^{23}$

A particularidade do relato feminino, as situações únicas vivenciadas por elas, como a vergonha diante da nudez forçada perante os oficiais nazistas, perante os médicos, são questões que passam pelo universo do tormento físico e mental observados, respectivamente, nos relatos de Blanka Rothschild, que foi deportada com sua mãe para o campo de Ravensbrück e Henny Fletcher Aronsen, deportada para o campo de Stutthof, onde foi colocada em um grupo de trabalhadores escravos

Nossas roupas foram tiradas. Passamos por um exame médico que era muito mais do que constrangedor. Nós éramos jovens garotas que nunca tinham feito exames ginecológicos, e eles estavam procurando por, só Deus sabe, diamantes ou coisa assim. Nós fomos submetidas a isso. Eu nunca havia visto uma cadeira como aquela antes na minha vida. Nós éramos humilhadas o tempo todo. ${ }^{24}$

Assim que chegamos em Stutthof, os nazistas disseram para as mulheres saírem dos trens e que mais tarde reencontraríamos nossos, maridos e pais. Então, eu e a minha cunhada saímos do trem e acho, não tenho certeza, se eles tinham transporte. Ah sim, eles tinham caminhões abertos onde todas nós fomos empilhadas e levadas para Stutthof. Então, disseram para nós, claro, depois de levarem o meu casaco e as outras poucas coisas que estavam comigo, que eи não tinha tido tempo de levar algo comigo. Eu me agarrei na minha mãe e eles nos disseram para nos despirmos. Sabe, eles sempre tinham umas mesas atrás das quais sentavam-se jovens alemães. Eles nos mandavam entrar numa sala e nos despirmos. Despir-se quer dizer tirar tudo. Então, lá estava eu, ao lado de minha mãe, e de centenas de outras mulheres, totalmente nuas em frente a uma mesa com um monte de criminosos nos olhando. O que você pensaria em uma situação daquelas? Que eles eram criaturas de outro planeta. Porém, não eram de nenhum planeta, eles eram do inferno. Pensei: por que deveria me incomodar e me preocupar com eles, com o que eles viam em mim? Como a gente poderia se sentir humilhada tendo a mãe e parentas nuas junto a nós? Quero dizer, eu não tinha parentes lá, apenas a minha cunhada. E lá estava você, totalmente nua e eles olhando para você... Eu fiquei lá parada com eles nos olhando, até que nos mandaram entrar e tomar banho, e nos deram uniformes, os uniformes listrados. E foi assim que a nossa experiência começou. E isso é um campo de concentração. ${ }^{25}$

Os relatos de violência sexual passaram completamente despercebidos pela maioria dos historiadores. Porém, Rochelle Saidel, procurou saber o motivo de não se haver registrado essa violência. Mesmo com a existência de uma lei que proibia as relações sexuais entre arianos e judeus, muitos soldados alemães infringiam essas leis e, estupravam mulheres judias, e, geralmente, eles as matavam depois para evitar problemas. O sentimento de vergonha era tamanho que as sobreviventes sequer 
mencionavam sobre o assunto. Um dos motivos que geravam esse silêncio era, provavelmente, a vergonha de terem trocado sexo por pão, o que poderia garantirlhes a sobrevivência. ${ }^{26}$

Dentre as práticas de violência sexual, perpetradas pelos nazistas no Holocausto estavam estupro, coerção, humilhações e nudez. Poucos testemunhos abordam essa forma particular de sofrimento. Um dos motivos de ficarem emudecidas é que os nazistas eram oficialmente proibidos de manterem relações sexuais com as judias em virtude da aplicação das leis de Nuremberg, se fossem detidos, o que raramente acontecia, seria pela prática de contaminação racial ou profanação da raça. ${ }^{27}$

Na seleção para as práticas de violência sexual, as mulheres eram revistadas para verificar se haviam escondido alguma coisa, "com armas apontadas para as mulheres e meninas, forçavam-nas a se despirem e examinavam suas partes íntimas. Obrigavam-nas a subirem na mesa e pularem com as pernas abertas."28

Nas seleções para as sessões de destruição, as grávidas e mães com crianças de colo eram sistematicamente classificadas como "incapacitadas para o trabalho", e enviadas para os centros de extermínio, nas primeiras fileiras de prisioneiras a serem enviados para as câmaras de gás. Essas câmaras tinham capacidade para acomodar até 1200 pessoas ao mesmo tempo. Ali, a morte podia demorar até 20 minutos. Esse era o tempo em que se ouviam, através das paredes das câmaras, as batidas, os chutes e os gritos de desespero das vítimas que lutavam por suas vidas.

Apesar do sofrimento, mostravam o desejo de sobreviver, eram corajosas. Fritzie Weiss Fritzshall foi com sua mãe e seus dois irmãos enviados para Auschwitz. Só Fritzie sobreviveu fingindo ser mais velha e, portanto, uma trabalhadora mais forte. Em uma marcha da morte partindo de Auschwitz, Fritzie conseguiu fugir para uma floresta, onde foi liberta, posteriormente. Em seu relato, conta como elas lutavam para não serem selecionadas para o extermínio:

Precisávamos mostrar que ainda tínhamos força, tanto para trabalhar como para viver mais um dia. Lembro de algumas mulheres, elas estavam começando a ver o cabelo crescer, estavam começando a ter cabelos grisalhos, e elas pegavam um pedacinho de carvão do forno a lenha que ficava em uma barraca. Elas usavam esse carvão para tingir os cabelos, para que parecessem um pouco mais jovens. Você ficava com cabelos brancos com uns dezoito ou dezenove anos sob aquelas condições. Elas corriam...nós corríamos na frente de quem estivesse fazendo as seleções para mostrar que sobreviveríamos mais um dia. Se alguém tivesse uma cicatriz, uma espinha, se não corresse muito rápido, senão parecesse adequado por qualquer motivo para aquela pessoa que estava fazendo a seleção, eles ficavam parados com uma vara, para a esquerda ou direita, conforme você corria para eles. Ninguém nunca sabia se estava na fila dos bons ou dos ruins. Uma fila ia para as câmaras de gás e a outra voltava para o campo e para as barracas para viver mais um dia. ${ }^{29}$

Nos últimos meses da guerra, chegavam a Ravensbrück as "grávidas de Varsóvia", mulheres violadas pelos soldados. No campo, na sala de partos, os bebês eram retirados de suas mães: mortos logo após o nascimento ou enviados para orfanatos nazis. Poucos ficavam ali para serem amamentados, por pouquíssimo tempo, porque as guardas deixaram de dar aveia e leite às mães para que não conseguissem amamentar e seus filhos morressem de fome. Entre 1944 e 1945, nasceram no campo cerca de seiscentas crianças, quase nenhuma sobreviveu. ${ }^{15}$

O campo de concentração para as mulheres, Ravensbrück, foi um lugar onde pode-se ver a natureza e a escala das atrocidades infligidas às mulheres. Muitas foram punidas, no lugar de outras que tentavam fugir. Dorotka (Dora) Goldstein Roth, sua irmã e sua mãe foram deportadas para o campo de Kaiserwald na Letônia e, em seguida, para o campo de Stutthof. Sua mãe e sua irmã morreram em Stutthof. A própria Dora foi baleada antes da sua libertação, mas sobreviveu. Relata que os castigos eram horríveis, ficarem nuas durante horas no frio e como se não fosse o suficiente, tinham que assistir a estupros de mulheres.

Sim, nós fomos punidas em Stutthof, eu ainda tinha a minha mãe e a minha irmã, e nós fomos punidas por causa de três mulheres que escaparam do campo. Sabe, recentemente estive em Auschwitz e vi os arames, e os fios de eletricidade e tudo voltou à minha mente naquele momento. Eu ainda não entendi como elas fizeram para escapar. Realmente não entendo, porque em cima... os fios de eletricidade nem sempre estavam ligados, mas quando viam alguém se aproximando demais ou tentando tocá-los, eles ligavam e elas morriam. Agora, como estas três mulheres não foram atingidas pelos fios elétricos, eu não sei. Mas elas escaparam. Eles não conseguiram encontrá-las. E nós fomos punidas, ficamos nuas durante doze horas no frio e o castigo adicional foi: eles levaram quatro ou cinco mulheres, não me lembro quantas mulheres, e, na frente das outras - ficamos em uma fila, sabe - eles estupravam de um modo que eu nunca havia lido ou visto em lugar algum, nem mesmo em filmes ou na televisão, e sabemos quanto a programação da televisão é ruim, com todos os tipos de histórias. E ver mulheres jovens serem estupradas por homens com pedaços de pau,...e minha mãe estava perto de mim e ela colocou as suas mãos nos meus olhos,...eu não deveria ver uma relação sexual pela primeira vez. Eu nunca havia visto uma relação sexual. $^{30}$

Como se não bastassem as crueldades feitas às mulheres, foram montados bordéis por Heinrich Himmler, o chefe de segurança de Hitler. Ele acreditava profundamente na potência sexual dos homens. Pensava que frequentar bordéis poderia forçar os homens a trabalharem mais, e que o próprio ato sexual teria uma enorme capacidade de revigorar o trabalhador e ampliar a sua produtividade. ${ }^{31}$ 
Sommer ${ }^{31}$ elaborou uma pesquisa, e verificou que o esquema de Himmler era de recompensas para os prisioneiros, em que "realizações particulares" lhes garantiam menor carga de trabalho, alimento extra, bônus financeiro e "o fornecimento de mulheres trabalhadoras em prostíbulos".

O primeiro bordel foi criado no campo de concentração de Mauthausen em 1942, e em seguida o programa foi levado a dez outros campos, incluindo os maiores, como Buchenwald, Dachau, Ravensbrueck, Sachsenhausen e Auschwitz. O último foi criado em 1945, poucos meses antes do término da guerra.

Os membros da SS agenciavam estrangeiras acusadas de serem contra o regime nazista, forçavamnas à prostituição. Muitas que sobreviveram, ficaram psicológica e fisicamente arruinadas no fim da guerra, pois eram cruelmente maltratadas nos "alojamentos especiais". Recrutavam as consideradas "antissociais", como desempregadas, pedintes e alcoólatras. Prometiam que o trabalho sexual duraria apenas seis meses e depois seriam libertas. Mas, não era assim que acontecia. Prisioneiras saudáveis e de boa aparência, entre 17 e 35 anos, atraíam a atenção dos recrutadores da SS. Mais de $60 \%$ delas eram alemãs, mas havia também polonesas e soviéticas, transferidas para "a força-tarefa especial". Elas recebiam injeções de cálcio, banhos desinfetantes, alimentos e um banho de luz. Nos campos, elas eram marcadas com um triângulo preto. $\mathrm{O}$ serviço funcionava de 7 às $22 \mathrm{~h}$ e só fechava na falta de água ou luz, durante ataques aéreos e a transmissão dos discursos de Hitler. Os encontros, eram em quartos de madeira, vigiado por um soldado. As mulheres, raramente engravidavam, mas quando acontecia uma gravidez, a mulher era substituída e enviada para um aborto. ${ }^{31}$

\section{A libertação}

A partir do momento em tomaram conhecimento da mentira, a SS começou a selecioná-las à força. Quem suportava a dureza da vida em um bordel tinha mais chances de escapar da morte. Quase todas sobreviveram ao regime de terror nazista, no entanto, quase nada se sabe do que aconteceu a elas, depois da guerra. A maioria manteve silêncio pelo resto de suas vidas. ${ }^{31}$

Os russos chegaram e procuram algumas moças, sabe como é, fingimos que estávamos muito doentes para que não tocassem em nós. Eles eram uns animais, porque não tinham estado com uma mulher há muito tempo, pouco lhes importando se ela está em um campo de concentração, se está doente, se tem piolhos ou não. Não ligavam, e estupraram algumas moças. Por isso tivemos de nos esconder debaixo das camas e de outras coisas. Foi uma luta o tempo todo. ${ }^{16}$

Nos relatos das sobreviventes observa-se que a memória e o esquecimento travam conflitos entre o lembrar e o esquecer. Algumas desejam esquecer a todo custo, mas, nem sempre o conseguem; há outras que não querem esquecer. A memória, vinculada ao passado, guarda para lembrar no futuro, e cria expectativas para fazê-lo ou não. E, no presente, o esquecimento se mostra, por meio da ausência ou presença. Totalmente seguro de si.

Na perspectiva ricoeuriana, o esquecimento é a personagem principal do reconhecimento, considerada a operação mais importante da memória. $\mathrm{O}$ esquecimento de reserva, aquele sobre o qual se diz que esqueceu, pode ser evocado novamente, ou seja, reconhecer por meio de um esforço possível da memória. É como apagar algo, não de forma total, mas com "reservas", um esquecimento benéfico, uma representação positiva do esquecimento, reversível, inesquecível. Assim, quando se quer lembrar, busca qualquer fragmento do passado, considerado completamente perdido.

$\mathrm{Na}$ suposição de se preservar a memória, sustenta-se que as sobreviventes do holocausto usaram o esquecimento de reserva, subjacente, colocado como a dimensão do esquecimento que considerou o reconhecimento do que se teve e retornou como parecendo novo/original. Assim como o relato de Charlene Schiff, que sobreviveu nas florestas próximas a Horochow. Foi liberta pelas tropas soviéticas. Emigrou para os Estados Unidos. No relato, relembra como sobreviveu depois de fugir do gueto de Horochow.

Como eu vivia na floresta, ou nas florestas, no plural? Eu não sei, mas é uma coisa incrível, quando se está com fome e completamente desmoralizado, você se torna criativo. Eu nunca... mesmo quando falo sobre isso, eu não acredito. Eu comi minhocas. Eu comi insetos. Eu comi qualquer coisa que eu pudesse pôr na boca. E, eu não sei, de vez em quando eu ficava muito doente. Havia alguns cogumelos selvagens, tenho certeza de que eles eram venenosos, não sei. Eu estava doente. Meu estômago estava ruim, mas mesmo assim pus o cogumelo na boca porque precisava mastigar alguma coisa. Eu tomei água de poças, neve. Qualquer coisa que eu conseguisse. Algumas vezes, eu entrava escondida em depósitos de batatas que os fazendeiros tinham perto das vilas. Esses eram bons lugares para se esconder porque eram um pouco mais quentes no inverno. Mas lá também havia roedores e tudo. E comer ratos crus, sim, eu comi. Com certeza, eи queria muito, muito mesmo, continuar viva, porque fiz coisas indescritíveis. Eu comi coisas que ninguém imaginaria ser capaz de comer. De alguma forma eu sobrevivi. Eu não sei por quê. Continuo me perguntando isso. Mas sobrevivi. ${ }^{32}$

Finalmente, em 1944, o Comité Internacional da Cruz Vermelha começou a receber informações, por meio de prisioneiras que escaparam, sobre os crimes de guerra, crianças esterilizadas, sobre as cirurgias nos músculos e ossos das mulheres para experimentos atrozes. Também foram informados de que à menor coisa ou dependendo do estado de espírito, as prisioneiras eram mortas a tiros. ${ }^{15}$

Em março e abril de 1945, a Cruz Vermelha sueca conseguiu libertar milhares de mulheres de Ravensbrück com a concordância do chefe da SS, Heinrich Himmler. Em 27 e 28 de abril, as mulheres 
restantes e que podiam andar foram forçadas a uma marcha da morte. Quando o Exército Vermelho libertou o campo de Ravensbrück, foram encontradas somente três mil mulheres, todas muito doentes.

Definir o horror vivido por elas, naquele local, sobre aquela época, é impossível. A dor de se chegar a um fim tão doloroso e de sobreviver presas às memórias, é como evocar os fantasmas do extermínio.

As experiências narradas desenham uma figura feminina com ressentimentos e dores, mas também com coragem para garantir que nada ficará perdido.

\section{Conclusão}

Refletir sobre relatos de mulheres sobreviventes do Holocausto, na Segunda Guerra Mundial, confirma que a relação indissociável entre a memória e o esquecimento permite entender o silêncio, o relato da dor, a superação e a possibilidade de recomeçar a escrita de uma história.

Os relatos restauram o que foi vivido e garantem a construção de uma história para a preservação da identidade. Consolida-se, assim, o compromisso de, ao desvelar todo o sofrimento e violência vividos por elas, não se esquecer e de jamais se repetir.

\section{Declaração de conflitos de interesses}

Os autores do artigo afirmam que não houve nenhuma situação de conflito de interesse, tais como propostas de financiamento, emissão de pareceres, promoções ou participação em comitês consultivos ou diretivos, entre outras, que pudessem influenciar no desenvolvimento do trabalho.

\section{Referências}

1. AGOSTINHO, Santo. Confissões. Trad. J. Oliveira Santos. S.J., e A. Ambrósio de

Pina, S. J. Editora Nova Cultural. São Paulo, 2001.

2. AVEY, Denis; BROOMBY, Rob. O homem que venceu Auschwitz: uma história real sobre a Segunda Guerra. Rio de Janeiro: Nova Fronteira, 2011

3. ROSSI, Paolo. O passado, a memória, o esquecimento: seis ensaios da história das idéias. Trad. Nilson Moulin. São Paulo: UNESP, p. 5. 2010.

4. HEIDEGGER. Martin. Sobre a essência da verdade. Tradução Ernildo Stein. São Paulo: Abril Cultural, 1973, p. 325-343. Coleção Os pensadores

5. GAGNABIN, J.M. Verdade de memória do passado. In: Lembrar escrever esquecer. São Paulo. Editora 34. 2006, p. 47

6. BERGSON, Henri. Matéria e memória. São Paulo: Martins Fontes, 1990.
7. ARRIGUCCI JÚNIOR, Davi. Móbile da Memória. In: Enigma e comentário. Ensaios sobre literatura e experiência. São Paulo: Companhia das Letras, 1987

8. LEVY, Sofia Débora. Holocausto: vivência e retransmissão. Perspectiva, 2014.

9.KONIG, Nanette Blitz. Eu sobrevivi ao Holocausto. Universo dos Livros, 2015.

10. ENCICLOPEDIA DO HOLOCAUSTO. Campos Nazistas - Testemunho: Ruth Webber. 1992. Disponível em: < https://www.ushmm.org/wlc/ptbr/article.php?Module $\mathrm{Id}=10005059>$ Acesso em: 14 mar 2017.

11. ENCICLOPEDIA DO HOLOCAUSTO. Campos Nazistas - Testemunho: Ruth Meyerowitz, 1990. MEYEROWITZ.1990. Disponível em: < https://www.ushmm.org/wlc/ptbr/article.php?Module Id=10005059> Acesso em: 14 mar 2017.

12. ENCICLOPÉDIA DO HOLOCAUSTO. Campos Nazistas -Testemunho: Deutsch Madelina, 1990. Disponível

em:https://www.ushmm.org/wlc/ptbr/media_oi.php? ModuleId=0\&MediaId=939 Acesso em 22 fev 2017 .

13. MORAIS, Fernando. Olga. 17 ed. Companhia das Letras, 2003.

14. ENCICLOPÉDIA DO HOLOCAUSTO. Campos Nazistas -Testemunho. Ruth Moser Borsos. 1990. Disponível em:https://www.ushmm.org/wlc/ptbr/media_oi.php? ModuleId=0\&MediaId=939 Acesso em 22 fev 2017.

15. HELM, Sarah. Ravensbrück: a história do campo de concentração nazista para mulheres. Record, 2015.

16. SAIDEL, Rochelle, G. As Judias do Campo de Concentração de Ravensbrück. Tradução Antonio de Pádua Danesi. São Paulo: Editora da Universidade de São Paulo, 2009.

17. ENCICLOPÉDIA DO HOLOCAUSTO. Campos Nazistas -Testemunho: Hana Mueller Bruml.1990. Disponível em:https://www.ushmm.org/wlc/ptbr/media_oi.php? ModuleId=0\&MediaId=939 Acesso em 22 fev 2017 .

18. ENCICLOPÉDIA DO HOLOCAUSTO. Campos Nazistas -Testemunho: Cecilie Klein-Pollack. 1990 Disponível 
em:https:/www.ushmm.org/wlc/ptbr/media_oi.php? ModuleId=0\&MediaId=939 Acesso em 22 fev 2017.

19. RICCEUR, Paul. A memória, a história, o esquecimento. Trad. Alain François. Campinas, SP: Ed. Unicamp, 2007.

20. SILVA, Helenice Rodrigues. Narrar, transmitir, representar: o testemunho de um sobrevivente francês (Judeu e resistente) dos campos de concentração nazista. Revista Anos 90, Porto Alegre, v.15, n. 28 , p. 221-252, dez. 2008 .

21. FISCHER, Gabriella. Núcleo de História Oral. São Paulo [12 de novembro 2008 ]Acervo ArqshoahLEER/USP. Entrevista concedida a Lilian Souza e a Rachel Mizrahi Mizrahi.

22. ENCICLOPÉDIA DO HOLOCAUSTO. Campos Nazistas - Testemunho: Lily Appelbaum Malnik. 1990.

Disponível

em:https://www.ushmm.org/wlc/ptbr/media_oi.php? ModuleId=0\&MediaId=939 Acesso em 22 fev 2017.Lily Appelbaum Malnik

23. ENCICLOPÉDIA DO HOLOCAUSTO. Campos Nazistas - Testemunho: Irene Hizme, 1995. Disponível em:https://www.ushmm.org/wlc/ptbr/media_oi.php? ModuleId=0\&MediaId=939 Acesso em 22 fev 2017.

24. ENCICLOPÉDIA DO HOLOCAUSTO. Campos Nazistas -Testemunho: Blanka Rothschild, 1994. Disponível em:https://www.ushmm.org/wlc/ptbr/media_oi.php? ModuleId=0\&MediaId=939 Acesso em 22 fev 2017.

25. ENCICLOPÉDIA DO HOLOCAUSTO. Campos Nazistas -Testemunho: Henny Fletcher Aronsen, 1994. Disponível em:https://www.ushmm.org/wlc/ptbr/media_oi.php? ModuleId=0\&MediaId=939 Acesso em 22 fev 2017.

26. REVISTA ÉPOCA. Violência sexual na guerra: terror no Holocausto. Disponível em: <http://colunas.revistaepoca.globo.com/mulher7por7/ 2011/07/16/violencia-sexual-na-guerra-terror-noholocausto/.> Acesso em: 24 fev 2017.

27. GOLDENBERG, Myrna. Sexo, violación y supervivencia. La mujer judía e o Holocausto. In: Nuestra Memória. Publicacion del Museo Del Holocausto. Año XVI. No 34.
28. GILBERT, Martin. O Holocausto: História dos Judeus na Europa na Segunda Guerra

Mundial. Tradução de Samuel Feldberg, Nancy Rozenchan. São Paulo: Editora Hucitec, 2010.

29. ENCICLOPÉDIA DO HOLOCAUSTO. Campos Nazistas -Testemunho: Fritzie Weiss Fritzshall, $1990 . \quad$ Disponível em:https://www.ushmm.org/wlc/ptbr/media_oi.php? ModuleId=0\&MediaId=939 Acesso em 22 fev 2017.

30. ENCICLOPÉDIA DO HOLOCAUSTO. Campos Nazistas -Testemunho: Dorotka (Dora) Goldstein Roth. $1989 . \quad$ Disponível em:https://www.ushmm.org/wlc/ptbr/media_oi.php? ModuleId=0\&MediaId=939 Acesso em 22 fev 2017

31. SOMMER, Robert, Sexual Exploitation of Women in Nazi Concentration Camp Brothels. In: HEDGEPETH, Sonja M. e SAIDEL, Rochelle G. (Org.). Sexual violence against Jewish women during the Holocaust. Lebanon: Brandeis University Press, University Press of New England, 2010.

32. ENCICLOPÉDIA DO HOLOCAUSTO. Campos Nazistas -Testemunho: Charlene Schiff. 1993. Disponível em:https://www.ushmm.org/wlc/ptbr/media_oi.php? ModuleId=0\&MediaId=939 Acesso em 22 fev 2017 